\title{
Morphological and Molecular Analysis of Parasitoid Wasp, Cheiropachus quadrum (Hymenoptera: Chalcidoidea: Pteromalidae) Infesting Bark Beetles of Wide Host Trees
}

\author{
Ajaz Rasool $^{1}$, Tariq Ahmad ${ }^{1, *}$, Bashir Ahmad Ganai ${ }^{2}$, Shaziya Gull ${ }^{1}$ \\ ${ }^{1}$ Entomology Research Lab, Department of Zoology, University of Kashmir, India \\ ${ }^{2}$ Centre of Research for Development (CORD), University of Kashmir, India
}

Received January 22, 2020; Revised March 23, 2020; Accepted March 28, 2020

Copyright $\bigcirc 2020$ by authors, all rights reserved. Authors agree that this article remains permanently open access under the terms of the Creative Commons Attribution License 4.0 International License

\begin{abstract}
Cheiropachus quadrum Fabricius, 1787 (Hymenoptera: Chalcidoidea: Pteromalidae) is a Pteromalid parasitoid wasp infesting wood boring beetles predominantly family Scolytidae. Owing to their profound diversity and small size, their identification is bit tricky. The present study involves molecular analysis and morphological identification including new host record, distribution and key identification characters of species. Morphologically, Cheiropachus quadrum is easily characterised by its large propleura, maculate forewings and enlarged fore-femur. Cytochrome Oxidase gene 1 was used as marker gene for DNA barcoding purposes. Sequences edited and trimmed in BioEdit were submitted to GenBank for accession number generation. BLAST and MEGA tools were used for molecular analysis to confirm the corresponding taxonomy. Generated sequence was found to have no perfect identity matches and hence was morphologically confirmed and submitted as novel sequence to the database. Molecular characterisation involving phylogenetic analysis was performed with top hits from blast database using Neighbour Joining and Maximum Likelihood tree construction methods. It was found that the mean $\mathrm{A}+\mathrm{T}$ content is $74.19 \%$ and estimated Transition/Transversion bias $(R)$ is 0.71 . Among the COI sequences, we found no overlap between the maximum K2P distance within species $(0.02 \%)$ and minimum distance between species (3.6\%). Phylogenetic analysis concluded DNA barcoding is helpful for identification of parasitoid species and complements morphological taxonomy for easy identification purposes.
\end{abstract}

Keywords Cheiropachus quadrum, Identification, Taxonomy, Molecular Characterisation, GenBank, Phylogeny, Parasitoid

\section{Introduction}

Traditionally, morphological identification has been used to delimit a particular species, but with the advent of DNA barcoding, taxonomic identification has been boosted and complemented for any sort of identification crisis. DNA sequences of short standardised gene fragments also termed as DNA barcodes have been developed for species discrimination for animals, plants and Fungi. Most common DNA barcode in case of animals is a fragment of Cytochrome c oxidase (COI) gene of mitochondrial genome. Information retrieved from DNA barcodes has far reaching implications and applications beyond taxonomic studies which include rapid biodiversity assessment, food chain analysis, conservation biology, bio-security, identification of medicinal and pharmacological active compounds.

Pteromalidae (Hymenoptera: Chalcidoidea), is a large family of Chalcid wasps commonly known as pteromalids. These wasps primarily act as ectoparasitoids, endoparasitoids, parasitoids and hyperparasitoids [4]. Pteromalids are usually metallic with robust body size ranging from $1-48 \mathrm{~mm}$, tarsi 5 segmented and antennae consisting of eight to thirteen segments. These are richly represented and are found in all zoogeographical regions of world showing diversity in morphological and biological characters. Currently it contains 588 genera and 3506 species distributed in 30 subfamilies [13]. Acting as primary or secondary parasitoids, pteromalids attack other insect groups such as Coleoptera, Lepidoptera, Diptera, Hemiptera, Hymenoptera and some Arachnida in their 
various stages of development and hence are considered as economically important beneficial insects [34,5]. A few pteromalids are phytophagous, feeding on seeds, while some have been reported to make galls in plants or develop as inquilines. These are important part of biological control programmes worldwide and have played key role in control of various pests [7,25,34]. Boucek et al. [33] recorded a total of 63 species of Pteromalinae under 36 genera form India and adjacent countries. In addition, Sureshan [26] revised Pteromalinae of Indian subcontinent taxonomically, besides providing comprehensive information.

The Cheiropachus quadrum Fabricius (1787) (Hymenoptera: Chalcidoidea: Pteromalidae) was first reported from Kashmir by Buhroo et al. [1] while surveying natural enemy complex of Shot hole borer, Scolytus nitidus in apple orchards. It is the only known species of Cheiropachus found in India including J\&K. Its hosts mostly include Xylophagous beetles, e.g. Scolytidae, Cerambycidae, Curculionidae and Bostrichidae [13]. This species was also reported from Scolytus rugulosus (Muller) (Coleoptera: Scolytidae) on apple tree dead wood in Iran by Lotfalizadeh and Gharali [10]. Bark beetles (Coleoptera: Curculionidae: Scolytinae) predominantly infesting confers and broad leaved trees of temperate regions in Northern hemisphere are among the most destructive pests of the world forests. Natural enemies including Hymenopteran parasitoid species of Braconidae, Pteromalidae, Eurytomidae are known to be among key regulators of these pests. Bark beetle infestation and therefore, received much attention [8,21,14]. Morphological identification of Cheiropachus quadrum (Fabricus 1787) from India has been described by Sureshan [26] and Khanday et al. [2]. C. quadrum as sole representative of its genus in Palaearctic is easily recognizable from rest of Pteromalinae genera by large propleura, maculate forewings and enlarged fore-femur, although smaller specimens have reduced markings [17]. Host association of $C$. quadrum with cherry tree (Prunus avium) is reported first time from Kashmir Valley. DNA barcoding of Chalcid wasps from India is scanty. Only 58 species including 44 Trichogrammatidae, 5 Eulophidae, 7 Encyrtidae and 2 Torymidae species have been barcoded yet [3]. Molecular identification via DNA barcoding of $C$. quadrum species has not been done yet from India and hence has been complemented in this study in concert with morphological taxonomy for its taxonomic identification.

\section{Materials and Methods}

Sampling on the incidence of infestation was conducted in Botanical Garden, University of Kashmir, Srinagar, Jammu \& Kashmir, India (3407'50.5"N, 7450’00.9"E). Twigs and branches of cherry tree were cut and reared in glass jars $(55 \times 25 \times 30 \mathrm{~cm})$ covered with muslin cloth from first week of May to mid August 2017. Logs were examined continuously. After one week parasitoids emerged and were collected in tubes and preserved in alcohol (70\%) for further morphological studies. Besides, adult Chalcids were also collected live on the infested tree by using tube, $70 \%$ ethanol and fine brush. For morphological studies, specimen was card mounted and examined under LEICA S9D Stereozoom trinocular microscope (Leica Microsystems, Germany). For molecular studies and experimentation, specimen was then put in $90 \%$ alcohol and kept at $-20^{\circ} \mathrm{C}$.

\subsection{DNA Extraction}

Samples required for DNA isolation were preserved in $90 \%$ alcohol at $-20^{\circ} \mathrm{C}$. Samples were thoroughly washed with $90 \%$ alcohol and formaldehyde for $30 \mathrm{sec}$ to avoid contamination. The Genomic DNA was extracted using DNA extraction kit (Nucleospin Insect DNA kit from Macheray Nagel, Germany) following manufacturer's protocol. PCR reaction mixture of $25 \mu \mathrm{l}$ was prepared with following composition of $50 \mu \mathrm{l}: 5 \mu \mathrm{l}(10 \mathrm{x})$ of Taq assay buffer, $5 \mu \mathrm{l}$ of dNTPs (each in $10 \mathrm{mM}$ concentration), Forward primers and reverse primers each $0.2 \mu \mathrm{l}(10$ picomoles/ $\mu \mathrm{l}), \mathrm{MgCl}_{2}$ buffer $(1.5 \mathrm{mM}) \quad 3 \mu \mathrm{l}$, Taq Polymerase $0.2 \mu \mathrm{l}(1 \mathrm{U})$, DNA template $3 \mu \mathrm{l}$ and Mili Q or sterilised water $33.4 \mu \mathrm{l}$. The universal primers used to amplify the CO1 region were LCO1490 5'GGTCAACAAATCATAAAGATATTGG-3' (forward) and HCO2198 5'-TAAACTTCAGGGTGACCAAAAAA TCA-3' (reverse) (Folmer 1994). Amplification was done by using a Thermal Cycler (Biorad Laboratories, California) programmed to $95^{\circ} \mathrm{C}$ for 7 minutes, followed by 35 cycles of $95^{\circ} \mathrm{C}$ for 30 seconds, $53^{\circ} \mathrm{C}$ for 45 seconds and $72^{\circ} \mathrm{C}$ for 45 seconds and a final extension at $72^{\circ} \mathrm{C}$ for 10 minutes. Amplified products were separated on $1.2 \%$ agarose stained with ethidium bromide and visualized using a UV trans-illuminator. Sequencing reaction was done in a PCR thermal cycler (GeneAmp PCR System 9700, Applied Biosystems) using the BigDye Terminator v3.1 Cycle sequencing Kit (Applied Biosystems, USA) following manufactures protocol at Rajiv Gandhi Centre for Biotechnology, Kerala, India.

\subsection{DNA Sequence Analysis}

Sequence Chromatogram of forward and reverse reads was edited, trimmed and assembled into a single Contig using Codoncode Aligner version 8.0 (Codon code corporation) and BioEdit 7.2 [32]. The homology search for the resulting consensus sequences was performed by using Basic Local Alignment Search Tool (BLAST) [28] and identification option of Barcode of Life Data systems (BOLD) [30] against sequences in GenBank to confirm the corresponding sequence taxonomy. The generated 
COI consensus sequences have been deposited in National centre for Biotechnology Information (NCBI) GenBank database [6].

\subsection{Phylogenetic Analysis}

The homologous COI sequences from Genbank database (NCBI) were obtained for phylogenetic analysis by performing similarity searches of our query sequences using BLASTn search algorithm [28,6]. Identification algorithm of Barcode of Life Database was also used for comparison and analysis [30]. A threshold of 3\% variation between individuals for COI gene was used for differentiating putative species [24]. Only top hits (sequences) with high similarity score in BLASTn were considered and non-redundant species sequences were retained for further analysis. In our COI data set 20 sequences (Table 1) were chosen for phylogenetic analysis and were aligned using MUSCLE [27] multiple alignment program inbuilt in MEGA X with the default alignment parameters [29]. Pair wise distance between each sequence and the variable sites analyses of the aligned dataset were performed in MEGA X [29].

Table 1. Accession numbers used for the phylogenetic analysis

\begin{tabular}{|c|c|c|}
\hline S. no & Accession no. & Species/Genus/family \\
\hline 1 & MK423231 & Cheiropachus quadrum \\
\hline 2 & MK900673 & Cheiropachus quadrum \\
\hline 3 & KR370280 & Pteromalinae sp. \\
\hline 4 & KR368466 & Petromalinae sp. \\
\hline 5 & MG501706 & Cecidostiba sp. \\
\hline 6 & KR933704 & Cecidostiba sp. \\
\hline 7 & MG503664 & Cecidostiba sp. \\
\hline 8 & MH004457 & Pteromalus beduguaris \\
\hline 9 & MG501422 & Cecidostiba sp. \\
\hline 10 & MG784031 & Pteromalus sp. \\
\hline 11 & MG784020 & Pteromalus sp. \\
\hline 12 & KM559791 & Hypoteromalus percussor \\
\hline 13 & KR373453 & Pteromalinae sp. \\
\hline 14 & MG497507 & Pteromalinae sp. \\
\hline 15 & MG505112 & Pteromalidae sp. \\
\hline 16 & MG501818 & Pteromalidae sp. \\
\hline 17 & KR874803 & Pteromalus sp. \\
\hline 18 & KR793998 & Pteromalidae sp. \\
\hline 19 & KR369858 & Pteromalinae sp. \\
\hline 20 & KR793399 & Pteromalidae sp. \\
\hline
\end{tabular}

\section{Results}

\subsection{Morphological Identification}

Adult females were collected from Cherry tree infested with Scolytus beetles owing to the presence of minute holes and gallery pattern (Figure 1 and 2). Morphological identification was carried out on the bases of following characters; Female body length $3.4-4.8 \mathrm{~mm}$. Body dark green with metallic reflections, eyes ovoid light red, head facially with copperish tinge, antenna blackish-brown with formula 11263, scape cylindrical and paler brown. Wings hyaline, veins dark brown with two dark brown fuscuous clouds, speculum broad but curved marginally: one below postmarginal vein and one below parastigma reaching almost middle. Marginal vein slightly longer (1.33times) than Stigmal vein. Metasoma blackish with bluish reflection ventrally and dorsally. Anterior margin of clypeus slightly emarginated, Pronotal collar distinctly less wider than mesoscutum, posterior margin deeply emarginated. Mesoscutum with notauli incomplete, discernible by metallic blue reflection. Legs blackish brown, coxae concolorous with mesosoma. Profemur enlarged, blackish brown with broad tooth on ventral edge, hind tibiae pale brown with two conspicuous spines dorsally, 5 tarsomers light brown with two tarsal claws (Figure 3).

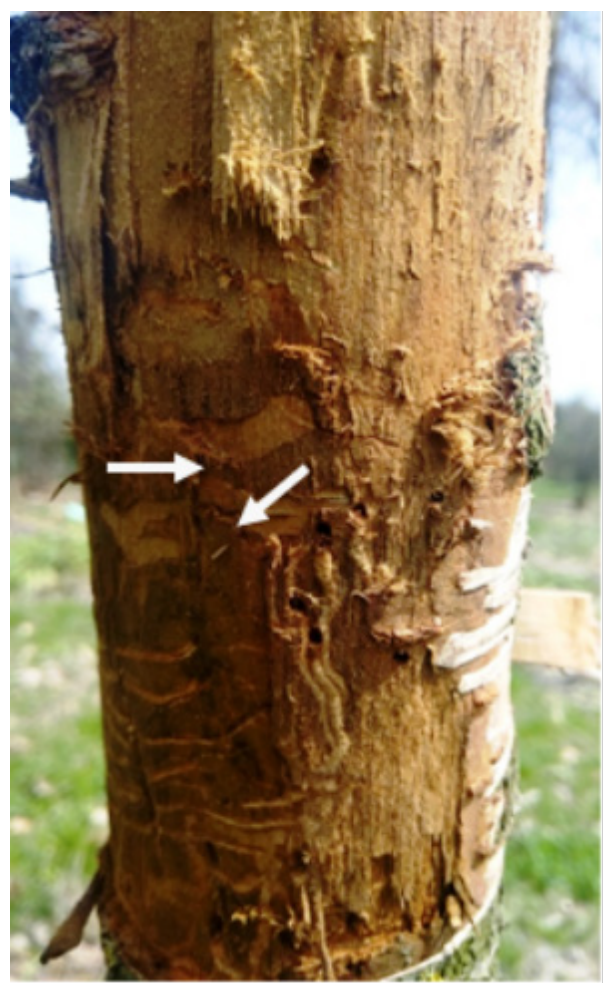

Figure 1. Exit holes in bark of Cherry tree (Host) 


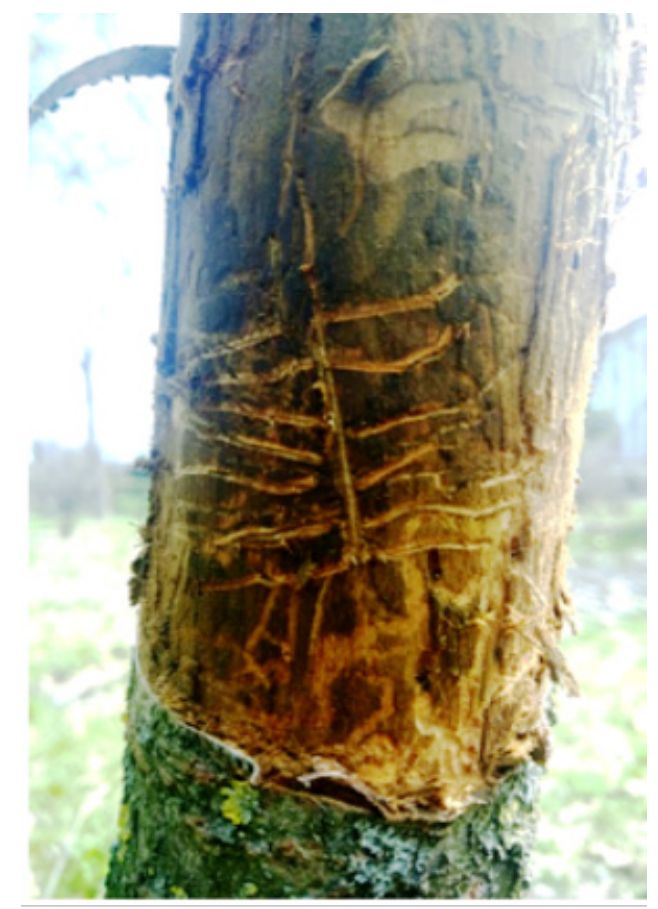

Figure 2. Gallery pattern of bark beetle

\section{(a)}
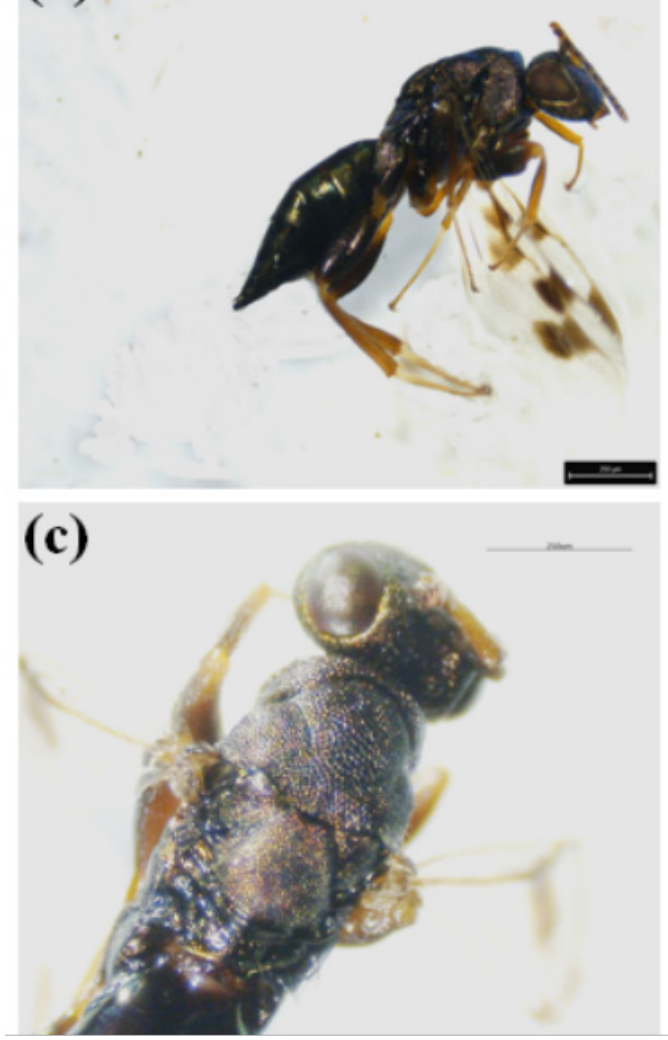
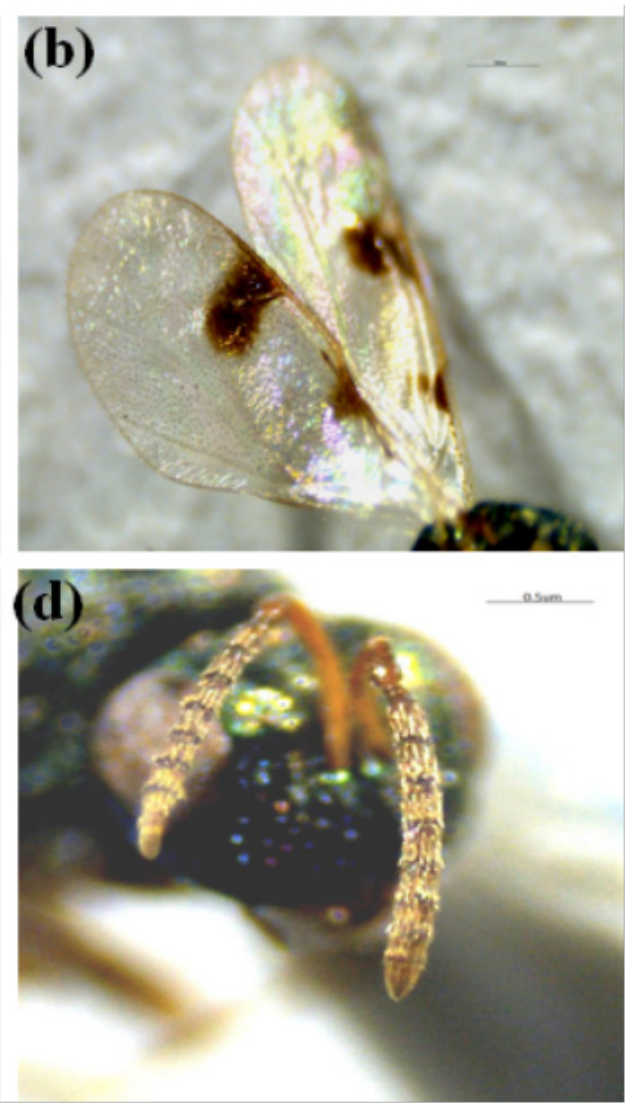

Figure 3. Cheiropachus quadrum (Fabricius), female: a, Habitus, lateral view; b, Fore wing, c, Mesosoma and Propodeum, dorsal view; d, Antennae 


\subsection{Material Examined and Host Association}

Card mounted Females, INDIA: Jammu \& Kashmir, Botanical garden, University of Kashmir $\left(34^{\circ} 07^{\prime} 50.5^{\prime \prime} \mathrm{N}\right.$, $74^{\circ} 50^{\prime} 00.9^{\prime \prime E}$ ), elevation $1600 \mathrm{~m}$ ), collected by Ajaz Rasool, May 2017, from stem of Cherry tree infested with Scolytus nitidus. Besides, Boucek et al. [33] reported it on Xylophagous beetles infesting cherry bark whereas Narendran et al. [31] reported it on apple tree infested with shot hole bark beetle, Scolytus sp. and Khanday et al. [2] described it on Pinus wallichiana infested by bark beetles.

\subsection{Distribution}

India (Jammu \& Kashmir and Himachal Pradesh), China (Tsinghai, Gansu, Nei Menggu, Shandong, Heilongjiang, Xinjiang Uygur), Pakistan, Great Britain, Spain, France, Norway, Germany, Sweden, Austria, Belgium, Switzerland, Poland, Italy, Czechoslovakia, Ukraine, former Yugoslavia, Georgia, Moldova, Armenia, Morocco, Iran, Lebanon, Macedonia, Moldovo, Netherlands, Azerbaijan, Turkey, Uzbekistan, Kazakhstan, Turkmenistan, Kirghizia, Tajikistan, North Africa, Russia (European part, North Caucasus, southern Far East), Egypt, Israel, Canada, Argentina, USA (California, New Hampshire, North Carolina, Washington, Oregon). Host records are based largely on those in the Universal Chalcidoidea Database and the present study [12] http://www.nhm.ac.uk/chalcidoids/.

\subsection{Molecular and Phylogenetic Analysis}

The accession number of the sequences so generated in
GenBank is MK423231 and MK900673. This is first time that barcoding of Chalcid wasps has been carried out from Kashmir valley. Due to dearth of molecular taxonomic data of Chalcid wasps in the BOLD and NCBI GenBank databases, our sequences were did not have perfect matches hence was submitted to Genbank only after morphological species confirmation. Translation of frame 3 of amino acid sequence containing 150 amino acids was performed using ExPASy bioinformatics resource portal [22]. After receiving accession numbers, final alignment of 20 top hit sequences was made each roughly $441 \mathrm{bp}$ long of which 4 represent Family Pteromalidae, 5 subfamily Pteromalinae, 4 represent genus Pteromalus, 1 Hypoteromalus and 4 represent Cecidostiba sp. The nucleotide composition in the generated sequences revealed a high A-T content $(74.19 \%)$, typical for arthropods which means for $\mathrm{A}=33.56 \%, \mathrm{G}=12.94 \%$, $\mathrm{C}=12.87 \%$ and $\mathrm{T} / \mathrm{U}=40.63 \%$ (Kumar 1980) (Table 2). To resolve barcode gap, phylogenetic trees based on two methods Neighbor joining (NJ) and Maximum likelihood (ML) were constructed in MEGA X. Both methods resulted in same topological structure; hence only Maximum likelihood method is shown here (Figure 4).

Table 2. Base Statistics of Cheiropachus quadrum COI gene

\begin{tabular}{|c|c|c|}
\hline $\begin{array}{c}\text { Genbank ID : } \\
\mathbf{4 2 3 2 3 1}\end{array}$ & $\begin{array}{c}\text { G+C Content }= \\
\mathbf{2 5 . 8 1}\end{array}$ & $\begin{array}{c}\text { A+T Content }= \\
\mathbf{7 4 . 1 9}\end{array}$ \\
\hline Nucleotide & Count & Percentage \\
\hline A & 150 & 33.56 \\
\hline T & 182 & 40.63 \\
\hline G & 54 & 12.94 \\
\hline C & 55 & 12.81 \\
\hline
\end{tabular}

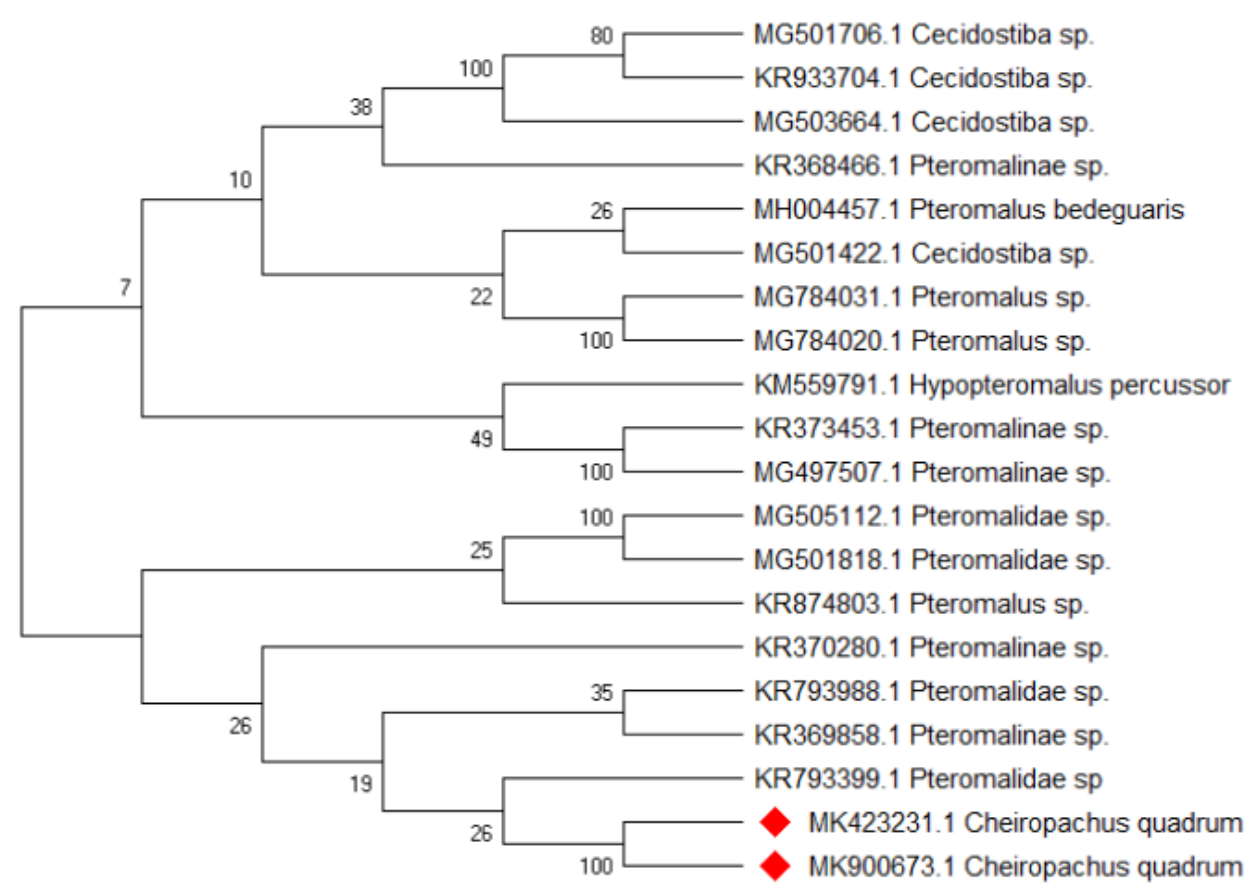

Figure 4. Maximum Likelihood tree based on COI gene sequences. Numbers indicate the percentage of 1000 bootstrap support values. sequences of the present study 


\section{Discussion and Conclusions}

Identification of an insect is prerequisite for studying its biology, behaviour, life cycle and role in various biological control programmes. Cheiropachus quadrum (Hymenoptera: Chalcidoidea: Pteromalidae), a common natural parasitoid of bark beetles infesting dead trees is of exemplary significance. Management of bark beetles by means of biological control programmes therefore requires information of natural enemies associated with them, their identification and role in population regulation of the particular pest. Morphologically, this parasitoid wasp has been characterised but molecular identification is missing. In this backdrop this study was carried out to identify the parasitoid associated with bark beetles by DNA barcoding of Mitochondrial Cytochrome C Oxidase gene I (COI) to complement morphological identification. Card pointed specimens were observed under Stereozoom trinocular microscope for Morphological analysis. Key characters like large propleura, maculate forewings and enlarged fore-femur were in consonance with that of Sureshan [22] and Khanday et al. [2]. Molecular data analysis was done involving genetic distance and phylogenetic tree construction. The final alignment of the COI data set resulted in total of 441 nucleotide sites having 323 conserved sites, 118 variable sites, 32 singleton sites and 86 parsim-info sites. The mean A +T content were $53.87 \%$. The data were analyzed for sequence divergence at different taxonomic levels of the data was carried out and analyzed in MEGA X software. A somewhat hierarchical increase in K2P mean divergence was observed among specimens at various taxonomic levels. Pairwise distance using K2P parameter in MEGA X was used to calculate the distance matrix and [29]. Codon positions included were $1 \mathrm{st}+2 \mathrm{nd}+3 \mathrm{rd}+$ Noncoding. All positions with less than $95 \%$ site coverage were eliminated. That is, fewer than $5 \%$ alignment gaps, missing data, and ambiguous bases were allowed at any position. The COI sequences showed interspecific divergence within the range of 3.06-11.6\%. Intraspecific COI sequence divergences were within the range of $0-0.02 \%$. No overlap was observed between maximum K2P distance within species and minimum distance between species. Cheiropachus isolates showed genetic difference of only $2 \%$, clustered together in a clade and hence were confirmed as same species. Substitution pattern and rates were also estimated under the Kimura 2-parameter model [15] (Table 3). Rates of different transitional substitutions are shown in bold whereas transversional substitutions are shown in italics. In addition, the estimated Transition/Transversion bias $(R)$ is 0.71 [15]. High nucleotide variations indicate geographical isolation and hence limited gene flow between species [9].
Table 3. Maximum Likelihood Estimate of Substitution Matrix (Transitional substitutions in bold and Transversional in italic)

\begin{tabular}{|c|c|c|c|c|}
\hline & $\mathbf{A}$ & $\mathbf{T} / \mathbf{U}$ & $\mathbf{C}$ & $\mathbf{G}$ \\
\hline $\mathbf{A}$ & - & 7.29 & 7.29 & $\mathbf{1 0 . 4 2}$ \\
\hline $\mathbf{T} / \mathbf{U}$ & 7.29 & - & $\mathbf{1 0 . 4 2}$ & 7.29 \\
\hline $\mathbf{C}$ & 7.29 & $\mathbf{1 0 . 4 2}$ & - & 7.29 \\
\hline $\mathbf{G}$ & $\mathbf{1 0 . 4 2}$ & 7.29 & 7.29 & - \\
\hline
\end{tabular}

Neighbor joining and Maximum Likelihood method were used for phylogenetic analysis. In both the methods congeneric species cohesively clustered together with closely related genera. Besides, taxa belonging to a particular family and subfamily more often than not formed a coherent cluster indicating that $\mathrm{CO} 1$ gene sequences are useful in identification of species. The evolutionary history was inferred by using ML and Kimura 2-parameter model so as to look for clustering of clades in different trees. The bootstrap consensus tree inferred from 1000 replicates is taken to correspond to the evolutionary history of the taxa analyzed [11]. Branches corresponding to partitions reproduced in less than 50\% bootstrap replicates are collapsed. The percentage of replicate trees in which the associated taxa clustered together in the bootstrap test (1000 replicates) are shown next to the branches [11]. Initial tree(s) for the heuristic search were obtained automatically by applying Neighbor-Join and BioNJ algorithms to a matrix of pairwise distances estimated using the Maximum Composite Likelihood (MCL) approach, and then selecting the topology with superior log likelihood value. Evolutionary analysis was conducted in MEGA X and involved 20 nucleotide sequences having a total of 441 positions in the final dataset [29]. The tree built with Pteromalidae entries has two major clusters. The taxa belonging to the same family or genus clustered together with healthy bootstrap support. It was also found that sequences from same country and genus or family clubbing in the same clade in both trees with high bootstrap values. Cheiropachus quadrum isolates of the current clustered together to form a single clade with $100 \%$ bootstrap value in consonance with the morphological study. Low bootstrap values in some clades were also recorded due to geographical isolation which also can result in less chance of gene flow creating more differentiation between them [18]. Therefore, molecular analysis supported morphological results, besides adding its barcode to the databases for further exploration. Considering the role of Cheiropachus quadrum in biological control programmes, sequence data of this study will serve as an elite DNA barcode for species identification, future molecular studies, better understanding of biocontrol services and other related taxonomic studies in future. 


\section{Conclusions}

Cheiropachus quadrum is well known parasitoid of scolytid beetles infesting various tree species of economic importance. Morphologically Cheiropachus quadrum species has been defined and described in India and in Kashmir valley, but molecular taxonomy was missing. There was rarely an entry in the Genbank database for the species C. Quadrum. This study was carried to add to knowledge of Chalcid wasps from Kashmir valley and also complement its morphologically defined taxonomy. Cytochrome C Oxidase gene I of mitochondrial genome was used as DNA barcode for the molecular analysis. The sequenced segment was found to be $411 \mathrm{bp}$ long and was found to be AT rich in content. The sequence showed low percentage of match in NCBI and BOLD database systems with the closest match being subfamily Pteromalinae (91\%). Phylogenetic analysis inferred close match between two isolates, clustering into same clade with good bootstrap support. Considering the obscurity in identification of diverse insect fauna owing to cryptic fauna, immature stages, or damaged specimens, this exercise will complement taxonomic analysis and sequence data will serve as an elite DNA barcode for species identification and other related taxonomic studies in future.

\section{Conflict of Interest}

The authors have no conflict of interest.

\section{Acknowledgements}

Authors are highly grateful to Head, Department of Zoology and Director, Centre of Research for Development (CORD) for providing working facilities. Besides, we are also thankful to Dr. Anzar Ahmad Khuroo, Assistant Professor and Rather Zubair, Research Scholar, Centre for Biodiversity and Taxonomy, Department of Botany, University of Kashmir for cordial help in photography of the specimens.

\section{REFERENCES}

[1] A. A. Buhroo, M. Z. Chishti, M. A, Masoodi, Biocontrol agents of shot-hole borer, Scolytus nitidus Schedl.(Coleoptera: Scolytidae) infesting apple orchards, Indian Journal of Plant Protection, Vol.30, No.1, 71-73, 2002

[2] A. L. Khanday, P. M. Sureshan, A. A. Buhroo, A. P. Ranjith, E. Tselikh, Pteromalid wasps (Hymenoptera: Chalcidoidea) associated with bark beetles, with the description of a new species from Kashmir, India, Journal of Asia-Pacific Biodiversity, Vol.12, No.2, 262-272, 2019
[3] A. Rasool, T. Ahmad, B. A. Ganai, S. Gull An overview of molecular identification of insect fauna with special emphasis on chalcid wasps (Hymenoptera: Chalcidoidea) of India, Acta Agriculturae Slovenica, Vol.111, 229-239, 2018

[4] B. R. Pitkin, "Pteromalidae", Universal Chalcidoidea Database, 2003 Online available fromhttp://www.nhm.ac.uk/chalcidoids/

[5] C. A. Desjardins, J. C. Regier, C. Mitter, Phylogeny of pteromalid parasitic wasps (Hymenoptera: Pteromalidae): Initial evidence from four protein-coding nuclear genes, Molecular Phylogenetics and Evolution,Vol. 45, 454-469, 2007

[6] D. A. Benson, I. Karsch-Mizrachi, D. J. Lipman, J. Ostell, E. W. Sayers, GenBank. Nucleic Acids Research, Vol 37, D26-D31, 2008

[7] D. J. Greathead, Parasitoids in classical biological control, Insect parasitoids, Academic Press, London, (1986)

[8] D. L. Dahlsten, Relationships between bark beetles and their natural enemies, Bark beetles in North American Conifers, University of Texas Press, Austin, 1982

[9] H. Kirk, J. R. Freeland, Applications and implications of neutral versus non-neutral markers in molecular ecology, International journal of Molecular Science, Vol.12, 39663988,2011

[10] H. Lotfalizadeh, B. Gharali, Pteromalidae (Hymenoptera: Chalcidoidea) of Iran: New records and a preliminary checklist, Entomofauna, Vol.29, 93-120, 2008

[11] J. Felsenstein Confidence limits on phylogenies: An approach using the bootstrap, Evolution, Vol.39, 783-791, 1985

[12] J. S. Noyes, Universal Chalcidoidea Database - World Wide Web electronic publication, 2017, Online available from http://www.nhm.ac.uk/chalcidoids/

[13] J. S. Noyes, Universal Chalcidoidea Database - World Wide Web electronic publication, 2010, Online available from http://www.nhm.ac.uk/chalcidoids/.

[14] M. Kenis, B. Wermelinger, J. C. Gregoire, Research on parasitoids and predators of Scolytidae-a review. Bark and Wood Boring Insects in Living Trees in Europe-A Synthesis, Kluwer Academic Publishers, Dordrecht, 2004

[15] M. Kimura, A simple method for estimating evolutionary rate of base substitutions through comparative studies of nucleotide sequences, Journal of Molecular Evolution, Vol.16, 111-120, 1980

[16] M. Nei, S. Kumar, Molecular Evolution and Phylogenetics, Oxford University Press, New York, 2000

[17] M. W. R. D. V. Graham The Pteromalidae of North-Western Europe (Hymenoptera: Chalcidoidea), Bulletin of British Museum (Natural History) (Entomology), Vol.16, 1-908, 1969

[18] M. Zhang, L. Kang Genetic divergence among geographical populations of the migratory locust in China, Science in China Series C: Life Sciences, Vol. 48, 551-564, 2005

[19] N. Saitou, M. Nei, The neighbor-joining method: A new method for reconstructing phylogenetic trees, Molecular 
Biology and Evolution, Vol.4, 406-425, 1987

[20] O. Folmer, M. Black, W. Hoeh, R. Lutz, R. Vrijenhoek, DNA primers for amplification of mitochondrial cytochrome c oxidase subunit I from diverse metazoan invertebrates, Molecular Marine Biology and Biotechnology, Vol.3, 294-299, 1994

[21] O. Sarikaya, M. Avci Predators of Scolytinae (Coleoptera: Curculionidae) species of the coniferous forests in the Western Mediterranean Region, Turkey Turkiye Entomoloji Dergisi, Vol.33, 253-264, 2009

[22] P. Artimo, M. Jonnalagedda, K. Arnold, D. Baratin, Csardi G, E. de Castro, S. Duvaud, V. Flegel, A. Fortier, E. Gasteiger, A. Grosdidier, C. Hernandez, V. Ioannidis, D. Kuznetsov, R. Liechti, S. Moretti, K. Mostaguir, N. Redaschi, G. Rossier, I. Xenarios, H. Stockinger, [23] ExPASy: SIB bioinformatics resource portal, Nucleic Acids Research, Vol. 40, W597-W603, 2012

[23] P. D. N. Hebert, E. H. Penton, J. M. Burns, D. H. Janzen, W. Hallwachs, Ten species in one: DNA barcoding reveals cryptic species in the neotropical skipper butterfly Astraptes fulgerator, Proceedings of Natural Academic of Science USA, Vol.101, 14812-14817, 2004

[24] P. Debach, M. Rose Biological control by natural enemies, 2nd ed. Cambridge University Press, Massachusetts, 1991

[25] P. M. Sureshan, Pteromalinae (Pteromalidae: Chalcidoidea: Hymenoptera) of Indian Subcontinent, Zoological Survey of India, Vol. 205, 1-170, 2003

[26] R. C. Edgar, MUSCLE: multiple sequence alignment with high accuracy and high throughput, Nucleic Acids Research,
Vol.32, 1792-97, 2004

[27] S. F. Altschul, T. L. Madden, A. A. Schäffer, J. Zhang, Z. Zhang, W. Miller, D. J. Lipman, Gapped BLAST and PSI-BLAST: a new generation of protein database search programs, Nucleic Acids Research, Vol. 25, 3389-3402, 1997

[28] S. Kumar, G. Stecher, M. Li, C. Knyaz, K. Tamura, MEGA X: Molecular Evolutionary Genetics Analysis across computing platforms, Molecular Biology and Evolution, Vol.35, 1547-1549, 2018

[29] S. Ratnasingahm, P. D. N. Hebert, BOLD: The barcode of life data system (www.barcodelife.org), Molecular Ecology notes, Vol.7, 355-364, 2007http://dx.doi.org/10.1111/j.1471-8286.2007.01678.x

[30] T. C. Narendran, A. A. Buhroo, M. Z. Chisti, Taxonomic studies on four new species of Chalcidoidea (Hymenoptera) of Economic importance from Kashmir, India, Entomon, Vol.26, No.2, 147-159, 2001

[31] T. Hall, I. Biosciences, C. Carlsbad, BioEdit: an important software for molecular biology, GERF Bulletin of Bioscience, Vol.2, No.1, 60-61, 2011

[32] Z. Boucek, B. R. Subba, S. 1. Farooqi, A preliminary review of Pteromalidae (Hymenoptera) of India and adjacent countries, Oriental Insects, Vol. 12, 433-467, 1979

[33] Z. Boucek, J. Y. Rasplus, Illustrated key to West-Palearctic genera of Pteromalidae (Hymenoptera: Chalcidoidea), Institut National de la Recherche Agronomique (INRA), 140, 1991 